\title{
CAMBRIAN CORRELATION WITHIN THE PERIGONDWANA FAUNAL REALM
}

\author{
Wen T. CHANG \\ Nanjing Institute of Geology and Palaeontology. Academia Sinica. Chi-Ming- \\ Ssu. 39 East Beijing Road. Nanjing. 210008 . P. R. China. \\ E-mail: wtchang @juno.com
}

Chang, W.T. 1998. Cambrian correlation within the Perigondwana Faunal Realm. [Correlación del Cámbrico en el Reino faunístico de Perigondwana]. Revista Española de Paleontología, no extr. Homenaje al Prof. Gonzalo Vidal, 23-34. ISSN 0213-6937.

\begin{abstract}
Stratigraphic positions of Redlichioidea trilobites found in the Lower Cambrian of Morocco, Spain, South France, Sardinia, Jordan, Doberlug and Görlitz (both in Germany), and those from Central Asia, Himalayan region, Australia and Antarctica are correlated with that of the Chinese biostratigraphic scheme.

During the Middle Cambrian, biostratigraphic correlation between the Mediterranean region (including Morocco and Central Europe) and China is very difficult because of the complete absence of Paradovides-fauna in China. Based on shallow-shelf and open-shelf trilobite faunas, the Middle and Upper Cambrian biostratigraphy of the Near East, Central, South and Southeast Asia, Australia and Antarctica are correlated with that of both China's shallow-shelf and open-shelf biostratigraphic schemes. Late Cambrian trilobite faunas of eastern Asiatic affinities also occur in Morocco, Spain, South France and Turkey. So far, there is no trilobite fauna of the Late Cambrian Fengshanian Stage found in Europe.
\end{abstract}

Key words: Cambrian, trilobites, biostratigraphic correlation, Perigondwana Faunal Realm.

\section{RESUMEN}

Se correlacionan las posiciones estratigráficas de los trilobites Redlichioidea del Cámbrico Inferior de Marruecos, España, sur de Francia, Cerdeña, Jordania, Doberlug y Görlitz (ambos en Alemania), así como las de Asia central, Himalaya, Australia y la Antártida, con el esquema bioestratigráfíco de China.

Dada la completa ausencia de la fauna de Paradoxides en China, la correlación bioestratigráfica entre el área mediterránea (incluyendo Marruecos y España) y China es muy difícil para el Cámbrico Medio. Por medio de trilobites de facies nerítico-sublitoral somera y nerítico-sublitoral abierta se correlaciona la bioestratigrafía del Cámbrico Medio y Cámbrico Superior de Oriente próximo, Asia central, meridional y suroriental, Australia y la Antártida con las escalas bioestratigráficas de China, tanto para facies someras como abiertas. También aparecen faunas de trilobites del Cámbrico Tardío de afinidades asiáticas orientales en Marruecos, España, sur de Francia y Turquía. Hasta el momento, no se han encontrado en Europa trilobites del Piso Fengshaniense del Cámbrico Tardío.

Palabras clave: Cámbrico, trilobites, correlación bioestratigráfica, Reino faunístico de Perigondwana.

\section{INTRODUCTION}

In Southwest China the Lower Cambrian succession with rich trilobite faunas has been divided into 14 zones within four stages, which may be used as a correlation standard for the Lower Cambrian of the Redlichian Realm. It seems impossible to discuss the precise Middle
Cambrian correlation between China and the Mediterranean region, because the Paradoxidid fauna which dominated over this area is absent in China, southern Asia, Australia and Antarctica. During the Late Cambrian a few Upper Cambrian trilobite genera of eastern Asiatic affinities occur in Morocco, Spain, southern France, Turkey, Iran, Oman, Afghanistan, the Himalayan region and Thailand. 


\section{CAMBRIAN CORRELATION BETWEEN CHINA AND THE MEDITERRANEAN REGION}

(Fig. 1). The Precambrian-Cambrian boundary beds of Morocco have been studied in detail by Hupé (1953) and Sdzuy (1978) and many important earliest Cambrian fossils including trilobites have been collected. Among them Lemdadella is the oldest Cambrian trilobite so far known from the Lemdad area of Morocco. This genus is intimately related to Eoredlichia (Chang, 1984), which is a senior synonym of Pararedlichia, which occurs in the Fallotaspis tazemmourtensis Zone of Morocco (Pillola, 1991). Lemdadella occurs in the basal part of the Calcaire Supérieur, or in the uppermost part of the Série Lie de Vin. It seems reasonable that the Fallotaspis tazemmourtensis Zone together with Calcaire Supérieur should be equivalent to the Eoredlichia-Wutingaspis Zone in China. Genera referred to the Gigantopygidae and Saukiandidae (Saukianda, Longianda) from Amouslekien up to Tasousekhtien (upper Issendalen to Bani Stages of Geyer, 1990) in Morocco fall within the Chinese Tsanglangpuan Stage. The Moroccan Aguilizien (Tissafin Stage of Geyer, 1990) may be correlated with the Lungwang-miaoan Stage in China, but there is no palaeontological evidence. The Toushamian and Tissafinian Stages (Geyer and Landing, 1995) in Morocco include so many Paradoxides and ptychoparioid trilobites having typical European affinities, that the exact correlation of the Middle Cambrian between Morocco, Spain, South France, Sardinia, Bohemia, Turkey and China is very difficult. The Bailiella and Olentella Zones of Morocco mentioned by Geyer and Landing (1995) may tentatively be correlated with the Bailiella Zone of the Middle Cambrian Hsuchuangian Stage and the Upper Cambrian Changshanian Stage respectively.

In Spain, Pararedlichia is found in Hermida (province of Lugo) and Concha de Artedo (province of Oviedo), northern Spain (Liñán and Sdzuy, 1978); Dolerolenus, Lunolenus and Metadoxides from the Niveau I in Los Barrios de Luna (León province), also northern Spain (Lotze, 1961); and Lemdadella linaresae from the Pedroche Formation of Córdoba; they are very similar to the Lemdadella-Pararedlichia fauna of Morocco. Therefore Zone I of Hupé (1953) together with the Calcaire Supérieur of Morocco should be equivalent to the Pedroche Formation of Córdoba and to Niveau I of Lotze (1961: 466) in Spain. Both are regarded as correlative with the Lower Cambrian Chiungchussuan Stage of China. The Perrector and Saukianda faunules from Alanís (Sevilla province), south-western Spain, can more reliably be correlated with the B3 of the Banian Stage in Morocco (Geyer and Landing, 1995), which is equivalent to the Chinese Tsanglangpuan Stage. The presence of Redlichia at Huérmeda, near Calatayud (Zaragoza province), north-eastern Spain, suggests a late Tsanglangpuan age. A faunule comprising Pagodia, Lajishanaspis, Langyashania and Maladioidella from NE Spain (Shergold, Liñán and Palacios, 1983; Shergold and Sdzuy, 1991) indicates regional affinities with the Upper Cambrian Changshanian Stage.

Lower Cambrian sediments of the Montagne Noire, southern France, consist of the Grès de Marcory (base) overlain by the Alternances gréso-calcaires which in turn is overlain by the Masse carbonaté. Trilobites, Galloredlichia, Granolenus and Limouolenus occur in the three clastic members of the Alternances grésocalcaires. These trilobites are Chiungchussuan because Galloredlichia is a junior synonym of Eoredlichia (Chang, 1984; Pillola, 1991). Ferralsia Cobbold, 1935 from the late Lower Cambrian in South France is intimately related to Palaeolenus, or Pseudoprotolenella of Southwest China in cranidial and glabellar shape and in the glabellar furrows and may be a junior synonym. Palaeolenus is widely distributed in the late Tsanglangpuan Stage in Southwest China. Therefore the bed yielding Ferralsia in South France is of Tsanglangpuan age. Chelidonocephalus in the Middle Cambrian of South France is of both stratigraphic and biogeographic significance, because it is a genus of slope biofacies in the late Middle Cambrian of North Iran and because it also occurs in association with Paradoxides in Southeast Turkey. It is very interesting to note that Bergeronites and Prochuangia have been reported and illustrated in South France (Feist and Courtessole, 1984). The writer has already pointed out that specimens found from South France should be referred to Palaeadotes Öpik, 1967 rather than to Bergeronites Sun in Kuo, 1965 (Chang, 1989; 1996). Bergeronites is a shallow water endemic genus and is confined to the North China Platform, whereas Palaeadotes, a pandemic genus, appeared in the slope biofacies of Antarctica, Australia, North and South Europe, Turkey, Iran, Kazakhstan, Northern Siberia and China. With regard to Prochuangia, we do not know whether this genus occurs in association with Palaeadotes, or whether its stratigraphic position may be slightly higher than Palaeadotes. In China, Prochuangia usually occurs in the basal part of the Upper Cambrian Changshanian Stage. The bed yielding Palaeadotes in South France should be of Kushanian age.

The Lower Cambrian biostratigraphy and the trilobite fossils of Sardinia have been studied in detail (Rasetti, 1972; Pillola, 1991). Three groups, six formations and five trilobite zones are in descending order as follows:

\section{Iglesias Group}

Cabitza Formation

Campo Pisano Formation

2. Gonnesa Group

San Giovanni Formation

Santa Barbara Formation

1. Nebida Group

Punta Manna Formation

Dolerolenus bifidus Zone

Dolerolenus zoppii Zone

Dolerolenus longioculatus Zone

Matoppa Formation

Dolerolenus aff. courtessolei Zone

Iglesiella ichnusae Zone 


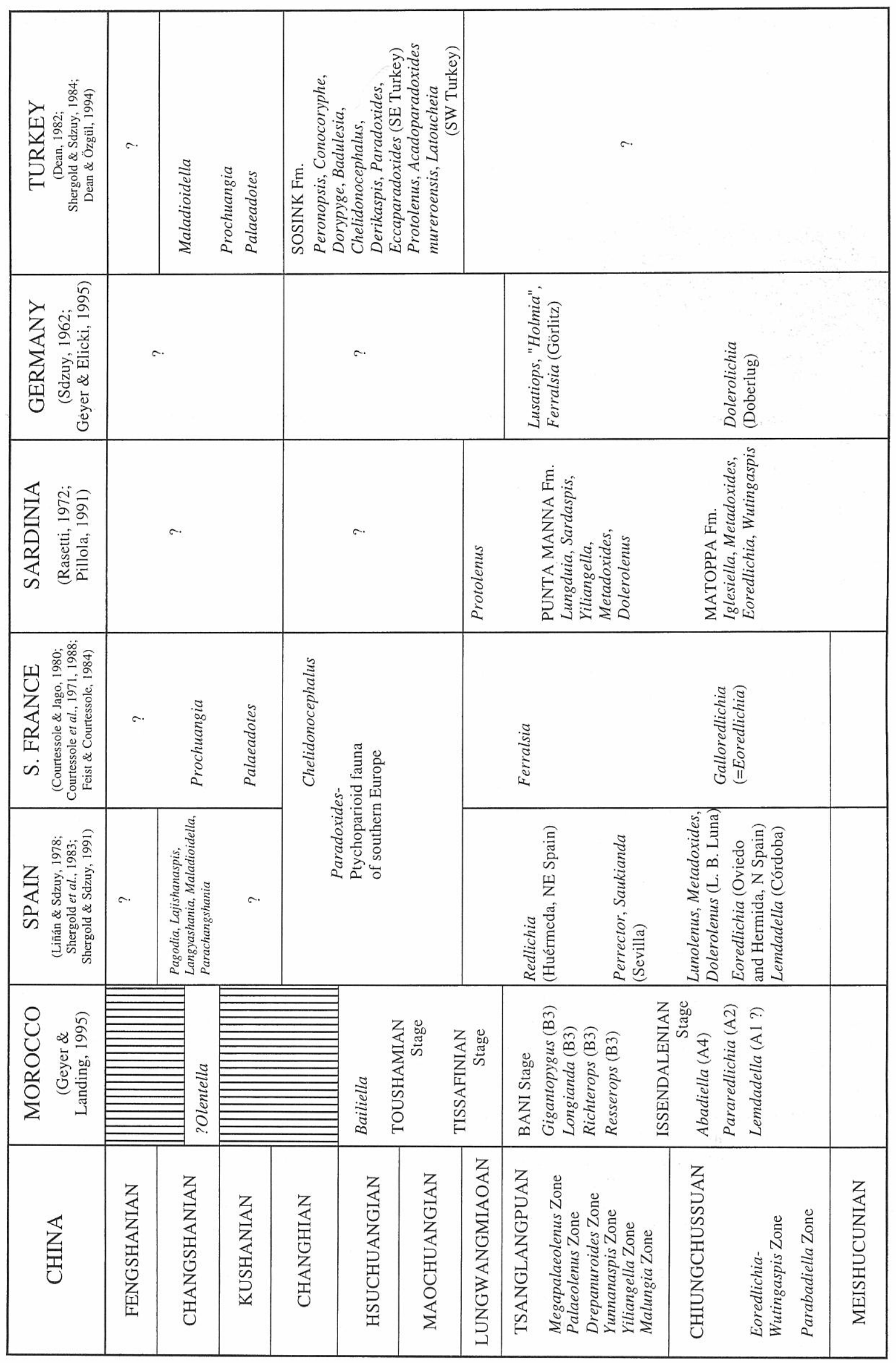

Figure 1. Cambrian correlation between China, the Mediterranean region and Central Europe. 
The Gonnesa and Nebida Groups are Lower Cambrian, while the Iglesian Group represents the Middle and Upper Cambrian (Pillola, 1991). The boundary between Lower and Middle Cambrian is drawn at a level within the lower part of the Campo Pisano Formation because specimens of typical Lower Cambrian trilobite Protolenus occur in the basal part of this formation. Judging by the stratigraphical range of those Lower Cambrian trilobites, the Punta Manna and Matoppa Formations fall within the late Chiungchussuan and early Tsanglangpuan or from Eoredlichia-Wutingaspis Zone up to the Drepanuroides Zone. Iglesiella closely resembles Chinese Metaredlichia, and Dolerolenus (Malungia) first appears in the upper part of the Eoredlichia-Wutingaspis Zone and goes up as high as the basal Tsanglangpuan. Genera such as Sardaspis, Longduia and Yiliangella in the Punta Manna Formation of Sardinia, are members of the Yiliangella to Drepanu-roides Zones of the early Tsanglangpuan. The Gonnesa Group and the basal part of the Campo Pisano Formation may be correlated with the late Tsanglangpuan and the whole Lungwangmiaoan, but direct palaeontological evidence is absent.

Dolerolichia from Doberlug ca. $90 \mathrm{~km}$ south of Berlin (Sdzuy, 1962) is closely related to Eoredlichia in the outline of cranidium and presence of preocular facial lines, but differs from the latter in having longer (exsag.) palpebral lobe and a larger multisegmented pygidium. This genus should be referred to the Saukiandidae and is of the same age as the Lemdadella-Pararedlichia fauna in Morocco. Doberlug is the northernmost occurrence of Redlichioid trilobites in Europe. At Görlitz, near the border between Germany and Poland, Richter and Richter (1941a) described a Lower Cambrian trilobite faunule which contains Lusatiops and Serrodiscus. Little was known of the age relationship of this faunule until Geyer and Elicki (1995) discovered Ferralsia and "Holmia" in association with the Lusatiops faunule at Görlitz (ca. 100 $\mathrm{km}$ southeast of Doberlug). As mentioned above, Ferralsia is similar to Palaeolenus, and the trilobites from Görlitz should be Tsanglangpuan.

In Turkey, Lower Cambrian trilobites are unknown. In southwest Turkey, early Middle Cambrian Acadoparadoxides mureroensis, Protolenus, Latoucheia and Corynexochella occur (Dean and Özgül, 1994). In southeast Turkey, the Sosink Formation contains Paradoxides, Eccaparadoxides, Dorypyge, Chelidonocephalus, Derikaspis, Badulesia, Peronopsis and Conocoryphe, which indicate a late Middle Cambrian age (Shergold and Sdzuy, 1984). Palaeadotes and Prochuangia, which also occur in Turkey (W. T. Dean, personal communication) have close affinities with the same faunule in South France, indicating the Kushanian. The Maladioidella and Pseudagnostus faunule of Shergold and Sdzuy (1984) is Changshanian.

\section{CAMBRIAN CORRELATION BETWEEN CHINA AND SOUTH ASIA}

(Fig. 2). Redlichops from the Dead Sea shore (Richter and Richter, 1941b) probably occurs in the same horizon as Lemdadella or Pararedlichia from Morocco or Spain because the posterior tip of the palpebral lobe of this genus is distant from the glabella, the palpebral lobe shorter than that of Redlichia, and the anterior section of facial suture relatively short and divergent, which are the primitive characters of the Redlichiidae. In the Dead Sea area, trilobites younger than Redlichops, such as Resserops, Myopsolenus, Kingaspis and Strenuella (Parnes, 1971) show affinities with the Mediterranean region, and are probably Tsanglangpuan or Lungwangmiaoan or both, but direct palaeontological evidence is lacking. The Lower Cambrian trilobite fauna from Jordan and Israel is different from that of Iran, Pakistan, Himalaya and China.

A late Cambrian trilobite succession from the Sultanate of Oman (Fortey, 1994), contains Fauna A, B, and C. Fauna A comprises Dipyrgotes and Torifera. Judging from the illustrations, the fragmentary specimen of a spinose pygidium should be referred to Fengduia (Zhu in Lu et al., 1974) rather than Dipyrgotes. Fengduia is a typical Damesellidae and occurs in the Kushanian of eastern Sichuan and southwestern Hubei (Lu et al., 1974: 106, pl. 42, figs. 5-9). Fortey's Fauna B contains Afghanocare, Prochuangia, Yokusenia and Maladioidella, of which the first three genera fall within the Chuangia Zone (s. l.) and the last within the younger Maladioidella Zone, both referred to the Changshanian. The Eosaukia trilobites of Fauna $\mathrm{C}$ are regarded as being pre-Tremadoc Fengshanian in age by Fortey.

The Cambrian trilobites of Iran have been studied by King (1930, 1937), Kushan (1973), Wolfart (1974a, b), Fortey and Rushton (1976) and Wittke (1984). Lower Cambrian deposits crop out in the Isfahan region and Kerman areas, of southwestern and southeastern Iran respectively. Middle and Upper Cambrian rocks occur in the Alborz Mountains, northern Iran. To the east of the Sultanate of Oman and Iran, the Cambrian faunas are all of east Asiatic affinities, including the Middle Cambrian. Therefore, it seems easy to correlate the Iranian Cambrian trilobite sequences with those of the current Chinese Cambrian biostratigraphic scheme. The Cambrian trilobite sequences of Iran are briefly summarized here, proceeding from the youngest faunas to the oldest as follows: 1. Saukia Zone, 2. Alborsella Zone, 3. Maladioidella Zone, 4. Prochuangia-Paracoosia Zone, 5. Palaeadotes-Torifera Zone, 6. Dorypyge-Chelidonocephalus Zone, 7. Iranoleesia Zone, 8. Kermanella Zone and 9. Redlichia Zone. Of which Zones 1 and 2 are regarded as Fengshanian; Zones 3 and 4 Changshanian; Zone 5 Kushanian. It seems necessary to point out that Spinopanura (Kushan, 1973) is a junior synonym of Palaeadotes. According to the range of Dorypyge, Zone 6 is late Changhian. With regard to Zone 7 , the nominate Iranoleesia (Reed, 1934; Kobayashi, 1967: 493) is very similar to the Chinese Proasaphiscus (Resser and Endo in Endo and Resser, 1937). This Chinese genus has a stratigraphic range from Hsuchuangian to basal Changhian. Therefore Zone 7 is provisionally correlated with the late Hsuchuangian. Based on Kermanella kuhbananensis as the type species, Wolfart (1974a) 


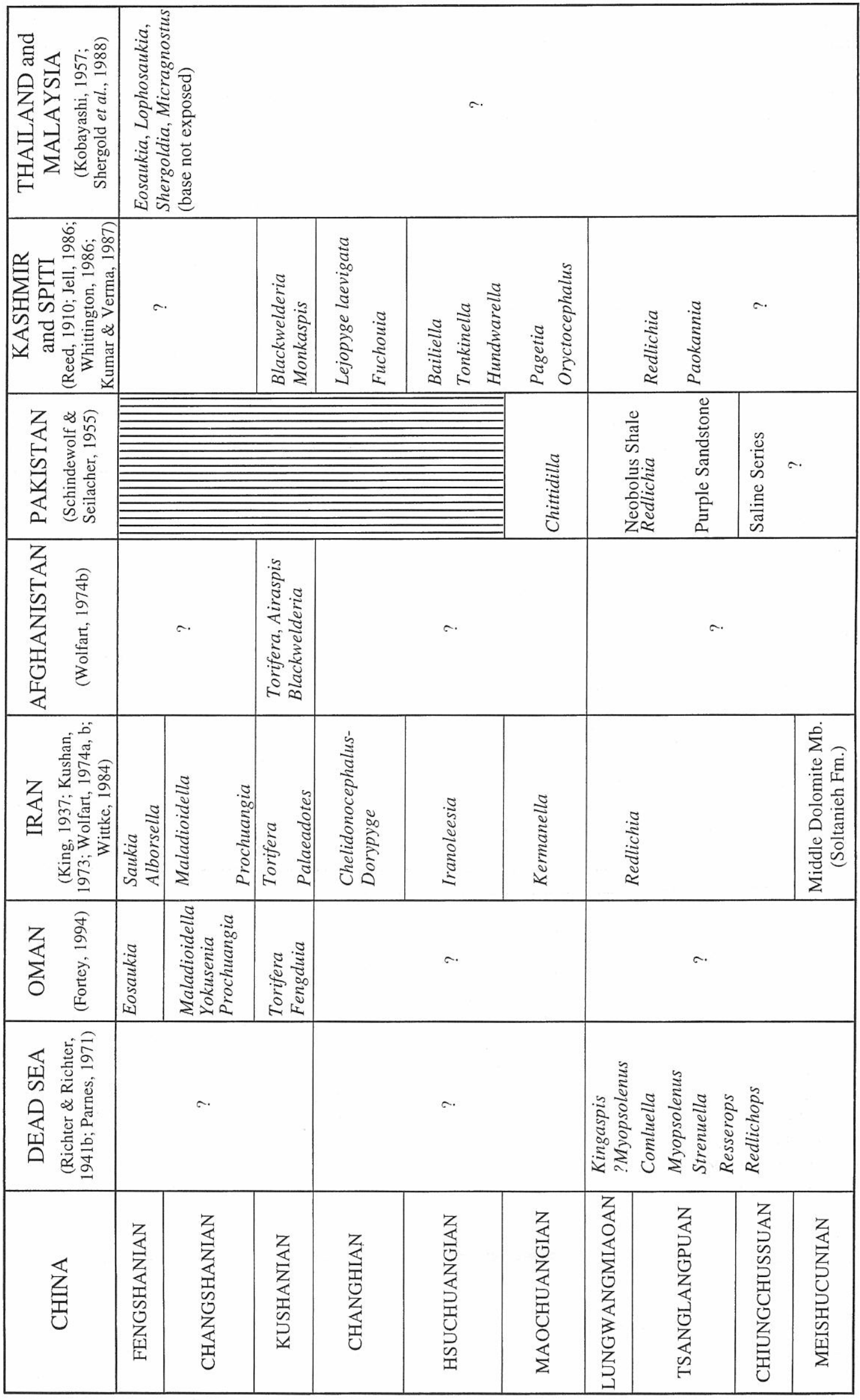

Figure 2. Cambrian correlation between China, Near East and South Asia. 
erected the genus Kermanella in the Ptychopariidae. In addition to the type species, $K$. lata is also referred to Kermanella (Wolfart, 1974a). Judging from the illustrations of Wolfart (1974a: pl. 8, figs. 1-2), K. lata minuta is close to Chittidilla of the Salt Range, Pakistan, and specimens of the same genus (Wolfart, 1974a: pl. 7, figs. 4a, 5a) are characteristic of the Chinese Kunmingaspis. Because both Chittidilla and Kunmingaspis are important component members of the early Middle Cambrian Maochuangian Stage, the Kermanella Zone is correlated with this stage. The oldest Redlichia Zone so far known in Iran may be regarded as late Tsanglangpuan. Cambrian fossils including trilobites and small shelly fossils which are older than the Redlichia fauna occur in northern parts of Iran. If the trilobites Eoredlichia and Wutingaspis occur in the Upper Shale Member of the Soltanieh Formation in the Dalir-Valiabad region, north of Tehran, the beds yielding those trilobites may correspond with the Chiungchussuan Stage; the Middle Dolomite Member, underlying the Upper Shale Member of the same formation, may be regarded as Meishucunian (Hamdi, 1989; Hamdi et al., 1989).

In the Kohe Taraka and Surkh Bum areas, Afghanistan, Cambrian trilobites including Torifera, Airaspis and Blackwelderia (Wolfart, 1974b) resemble Kushanian faunas in eastern Sichuan, southwestern China (Zhu in Chang et al., 1980).

The Cambrian sequences in the Salt Range, Pakistan and in Yunnan, Southwest China correspond closely lithologically and contain the same sequence of fossils (Chang, 1981). The Salt Pseudomorph Beds are composed of purple shales and sandstones and contain Chittidilla plana King, 1941 and some brachiopods. The Douposi Formation of Maochuangian age, well exposed in the Wuting and Luquan areas East Yunnan, is also composed of purple sandy shales yielding many specimens of Chittidilla (Chang et al., 1980). The Magnesian Sandstones (=dolomite) (Schindewolf and Seilacher, 1955), like the Shanyicun Formation (Luo et al., 1994) of Lungwangmiaoan Stage is dolomite to dolomitic limestone. The upper part of the Neobolus Shale contains Ptychoparia geei King, 1941, P. sakesarensis King, 1941 and Redlichia noetlingi (Redlich, 1899) and several different brachiopods including Botsfordia (King, 1941). The two species of Ptychoparia have been transferred to the late Early Cambrian Chinese Yuehsienszella (Chang, 1964). The Wulongqing Formation of the Upper Tsanglangpuan Stage consists of green sandy shales yielding serveral species of Redlichia and inarticulate brachiopods. The Hongjiangshao Formation, corresponding to the Purple Sandstone of Salt Range, is composed of purple sandstone and green shales and represents the lower Tsanglangpuan Stage in Southwest China. The only mismatch is between Heilinpu Formation (Luo et al., 1994) and rocks of the Meishucun Stage, which do not contain evaporites, and the Saline Series of Pakistan. Otherwise these two sections exhibit an extremely close correlation on lithologies, thickness and fossil contents (Chang, 1981: tab. 1).
The Cambrian trilobites of Spiti and Kashmir, Himalayan region, were described by Reed $(1910,1934)$. Lower, late Middle and early Upper Cambrian trilobites have been discovered from Kashmir and Ladakh by Whittington (1986), Jell (1986) and Kumar and Verma (1987). Based on the modern taxonomy of Cambrian trilobites and the current Chinese Cambrian biostratigrapic scheme, seven successive assemblages or faunules in descending order are revised as follows: 7 . Blackwelderia, 6. Lejopyge laevigata, 5.Bailiella, 4. Tonkinella, 3. Oryctocephalus-Pagetia, 2. Redlichia and 1. Paokannia. The Blackwelderia Zone, which contains Blackwelderia, Monkaspis and Cyclolorenzella is reported from the Trahagam Formation near the village of Trahagam, Hundwara, Tehsil, Kashmir. This fauna occurs in green shales and provides the first unequivocal Kushanian in the Himalayan region (Jell, 1986). The Lejopyge laevigata Zone contains Lejopyge laevigata, Diplagnostus cf. humilis, Fuchouia and Cyclolorenzella, and occurs in Zanskar, Ladakh, northern India, ca. 300 $\mathrm{km}$ southeast of Trahagam village. This fauna occurs in neighbouring areas, such as Malyj Karatau, southern Kazakhstan; Qurugtagh and Huocheng, both in Xinjiang, western China; western Hunan and western Zhejiang, South China. Undoubtedly it represents a fauna of slope biofacies and of late Middle Cambrian age (Whittington, 1986). Bailiella occurs in the Hundwara district, Kashmir, and it has a wide distribution in the late Hsuchuangian on the North China Platform and near the North Vietnam-southeastern Yunnan border (Reed, 1934; Chang, 1988). It is very interesting to note that Tonkinella has a wide geographic distribution in Utah, Nevada and Newfoundland (Sundberg, 1994), Kashmir (Reed, 1934; Kobayashi, 1934), North Vietnam (Mansuy, 1912, 1916), southeast Yunnan (Mansuy, 1912, 1916; Luo, 1984), central Shandong, western Henan and southern Liaoning (Chang, 1957; 1988; Chang et al., 1995), North and South Korea (Kobayashi, 1935) and Siberia (Tchernysheva, 1962). In North China the Poriagraulos Zone contains species of Tonkinella. The superjacent Bailiella Zone contains Ptychagnostus sinicus Lu, 1957. According to Robison (1984) this agnostoid species is a junior synonym of Ptychagnostus intermedius which is an important member of the Ptychagnostus gibbus Zone of North America. Judging from the palaeontological evidences mentioned above, the Bailiella and Poriagraulos Zones should be equivalent to the Ptychagnostus gibbus Zone. It should be also mentioned that species of Tonkinella from Siberia and North America occur in the same agnostid zone. Therefore species of Tonkinella found from Kashmir and Vietnam are of the same age. In eastern Guizhou the beds overlying the Bathynotus-Redlichia bearing rocks contain Oryctocephalus and Pagetia and represent the typical slope bio- and lithofacies in the eastern marginal part of the Yangtze Platform. The beds yelding Oryctocephalus, Pagetia and ptychoparioids in Kashmir are the equivalent beds of eastern Guizhou, of the Oryctocephalus beds in North Korea and central and northern Australia, and of the Oryctocephalus Zone of eastern Nevada and western 


\begin{tabular}{|c|c|c|c|}
\hline $\begin{array}{l}\text { MALYJ KARATAU } \\
\text { S. Kazakhstan } \\
\text { (Abdulin et al., 1984) } \\
\end{array}$ & CHINA & $\begin{array}{l}\text { AUSTRALIA } \\
\text { (Shergold, 1995) }\end{array}$ & \multirow[t]{2}{*}{$\begin{array}{c}\text { ANTARCTICA } \\
\text { (Cooper \& } \\
\text { Shergold, 1991) }\end{array}$} \\
\hline \multirow{2}{*}{ ORDOVICIAN } & \multirow{2}{*}{ ORDOVICIAN } & ORDOVICIAN & \\
\hline & & \multirow{2}{*}{$\begin{array}{c}\text { Datsonian } \\
\text { Payntonian }\end{array}$} & Fauna 7 \\
\hline \multirow{2}{*}{$\begin{array}{c}\text { Kazakhstanian } \\
\text { Aksaian }\end{array}$} & \multirow{2}{*}{ Fengshanian } & & \multirow[b]{2}{*}{ Fauna 6} \\
\hline & & \multirow{2}{*}{$\begin{array}{rr}\text { Iverian } & 4 \\
& 3 \\
& 2 \\
1 \\
\text { - Idamean } \\
\end{array}$} & \\
\hline Sackian & $\begin{array}{ll} & 4 \\
\text { Changshanian } & 3 \\
& 2 \\
1\end{array}$ & & Fauna 5 \\
\hline Ayusokkanian & Kushanian & Mindyallan & Fauna 4 \\
\hline $\begin{array}{c}\text { Zhanaarykian } \\
\text { Tyesaian }\end{array}$ & Changhian & $\begin{array}{l}\text { Boomerangian } \\
\text { Undilian } \\
\text { Floran }\end{array}$ & Fauna 3 \\
\hline Amydaian & $\begin{array}{l}\text { Hsuchuangian } \\
\text { Maochuangian }\end{array}$ & Templetonian & Fauna 2 \\
\hline $\begin{array}{l}\text { Toyonian } \\
\text { (Redlichia) }\end{array}$ & Lungwangmiaoan & \multirow{4}{*}{$\begin{array}{l}\text { Pararaia janeae } \\
\text { Pararaia bunyerooensis } \\
\text { Pararaia tatei } \\
\text { "Abadiella" huoi }\end{array}$} & \multirow{4}{*}{ Fauna 1} \\
\hline $\begin{array}{l}\text { Botoman } \\
\text { (Palaeolenus) } \\
\text { (Ushbaspis) }\end{array}$ & Tsanglangpuan & & \\
\hline $\begin{array}{l}\text { Atdabanian } \\
\text { (H. orientalis) }\end{array}$ & Chiungchussuan & & \\
\hline Tommotian & Meishucunian & & \\
\hline
\end{tabular}

Figure 3. Cambrian correlation between China, Kazakhstan, Australia and Antarctica. • Fengshanian: 3. Mictosaukia Zone; 2. Changia Zone; 1. Tsinania-Ptychaspis Zone. - Changshanian: 4. Kaolishania Zone; 3. Maladioidella Zone; 2. Changshania Zone (=Irvingella Zone); 1. Chuangia Zone. • Iverian: 4. Lophosaukia Zone; 3. Hapsidocare Zone; 2. Peichiashania Zone; 1. Irvingella Zone.

Canada. The Oryctocephalus beds in Kashmir and other parts of the world are early Middle Cambrian. In the Himalayan region the Redlichia Zone is regarded as the late Tsanglangpuan Stage and the Paokannia Zone (Kumar and Verma, 1987) is the oldest Early Cambrian trilobite zone in the region. Paokannia from the Vel Member of the Lolab Formation, Anantnag, $70 \mathrm{~km}$ southeast of Srinagar, Kashmir, which occurs in beds underlying Palaeolenus Zone in Southwest China, is regarded as early Tsanglangpuan.

Cambrian fossils were discovered in sandstone beds, known as the Tarutao Sandstone, or Formation (=Machinchang Formation in Malaysia) on Tarutao Island, Thailand (Kobayashi, 1957; Shergold et al., 1988). This formation is chiefly composed of purple, brown and micaceous sandstone, with intercalations of thin, argillaceaous tuffaceous beds and light brown siltstone, which represent very shallow waters of a tropical barrier-beach complex, where frequent storms redistributed much of the fauna and sediment. The thickness of Tarutao Sandstone has been estimated at 850 $\mathrm{m}$, but the base is not exposed. The trilobites including species of Micragnostus, Prosaukia, Eosaukia, Hoytaspis, Lichengia, Quadraticephalus, Parakoldinioidia, Szechuanella and Shergoldia (Shergold et al., 1988) are terminal Late Cambrian based on the occurrence of saukiid and leiostegiid genera. The exact age is regarded as equivalent to the Neoagnostus quassibilobus/ Shergoldia nomas Zone of the middle Payntonian, or of the lower part of the Mictosaukia Zone of the Fengshanian.

\section{CAMBRIAN CORRELATION BETWEEN CHINA, KAZAKHSTAN, AUSTRALIA AND ANTARCTICA}

(Fig. 3). We have discussed the correlation of Cambrian between China and Australia earlier (Chang and Jell, 1987; Chang, 1986). Based on the description of the Early Cambrian trilobites from South Australia (Jell in Bengtson et al., 1990), four trilobite zones have been proposed for the Lower Cambrian (in descending order), namely Pararaia janeae Zone, Pararaia bunyerooensis Zone, Pararaia tatei Zone and "Abadiella" huoi Zone, of which the lower zone could be correlated approximately with the Chiungchussuan Stage of China, while the upper three zones with the Tsanglangpuan Stage. The highest trilobite occurrence at the top part of Wirrealpa Limestone in South Australia is of Redlichia 
guizhouensis, that resembles Redlichia chinensis Walcott, 1905 in many respects, and Onaraspis from the Moodlatana Formation may correlate with the Lungwangmiaoan Stage of China and most probably with the Redlichia chinensis Zone (Bengtson et al., 1990: 1618). This correlation is approximately the same as the correlation proposed by Chang and Jell (1987). Moroccan Abadiella is different from Chinese Parabadiella in not only cranidial features but also stratigraphical occurrence (Chang et al., 1997: 461-462). Specimens from Australia referred to Abadiella (Jell in Bengtson et al.,1990: 277280) are similar to Wutingaspis rather than Abadiella. Dolerolenus sp. (Öpik, 1975: pl. 7, fig. 2) from the Parara Limestone near Kulpara, Yorke Peninsula, South Australia should be referred to Parabadiella. Redlichia beds in Antarctica and the Emu Bay Shale of Kangaroo Island, South Australia, are late Tsanglangpuan, whereas Redlichia chinensis and other species of Redlichia in western Queensland and Northern Territory are Lungwangmiaoan. With regard to the correlation of the Lower and Middle Cambrian boundary between China and Australia, some important evidences have been given by Kruse (1990). There are two fossiliferous intervals within the Tindall Limestone of the Daly Basin, Northern Territroy, Australia, of which the upper fauna is characterized by Xystridura, Gunnia and Tongshania; the lower fauna by Redlichia. According to Kruse, the upper fauna is correlated with the early Templetonian Peronopsis longinqua Zone, while the lower fauna with the late Ordian Redlichia chinensis Zone, and this same faunal succession is present also in the Thorntonia Limestone of western Queensland. Kruse also noted that Gunnia is close to Probowmania Kobayashi or Probowmaniella Chang of the early Maochuangian. A cranidium of Gunnia lutea Gatehouse (Kruse, 1990: 18, pl. 5) resembles closely the Chinese Kaotaia, which is an index genus confined to the Maochuangian in Southwest China. Thus the boundary between Templetonian and Ordian Stages in Australia is equivalent to the boundary between Maochuangian and Lungwangmiaoan (or Manto) Stages in China.

With regard to the age of Redlichia chinensis Walcott, 1905, a few palaeontologists suggest that it is early Middle Cambrian rather than late Lower Cambrian. Australian palaeontologists consider that there is faunal overlap of Redlichia and Xystridura in the Ordian Stage of Northern Territory. Succeeding the Ordian Stage is the Templetonian which has been divided into the upper Triplagnostus gibbus Zone and the lower Xystridura templetonensis Zone. Considering the xystridurid trilobites as a standard for the early Middle Cambrian in Australia, therefore, Redlichia chinensis or other species of Redlichia which occur in association with Xystridura, should be of early Middle Cambrian. I think this is the only reason why the Ordian is considered to be of early Middle Cambrian age (Öpik, 1975; Shergold et al., 1990). Within Australia, most species of xystridurids, oryctocephalids, ptychopariids (Gunnia, Tongshania) and Pagetia occur in the Templetonian, which represents the early Middle Cambrian of Australia. Xystridura and
Galahetes from Hainan Island, western Kansu and from western Xinjiang, do not coexist with Redlichia. Öpik (1975: 8) correlated the Ordian with the upper Botoman and Lenian (=Toyonian) Stages of Russia which has long since been considered Lower Cambrian by Russian geologists and also by Shergold et al. (1990). Xystridurid trilobites probably evolved from Early Cambrian protolenid trilobites, such as Hsuaspis. It seems reasonable that earlier species of Xystridura may coexist with some species of Redlichia. A similar case occurs in Morocco where the olenellid Kjerulfia appears in the Tasousekhtien Substage, and goes up as high as the base of Middle Cambrian, where it coexists with Acadoparadoxides and various protolenids, and some endemic olenellids can also be found, in the passage-beds from the Lower to the Middle Cambrian (Hupé, 1960: 75). Chang and Jell (1987) raised the problem whether the Payntonian Stage in Australia is equivalent to all or only the upper part of the Fengshanian. After a comparison of the trilobites within the interval between the Idamean and the Payntonian in Australia and the Changshanian of China, we arrived at the conclusion that the base of the $R$. clarki prolatus/C. sectatrix Zone coincides with the base of the Fengshanian (Chang and Jell, 1987: 32, 34). Some Australian palaeontologists suggest that the Fengshanian is totally equivalent to the Payntonian which includes in descending order the Mictosaukia perplexa, Neoagnostus quasibilobal Shergoldia nomas and Sinosaukia impages Zones (Shergold et al., 1990; Shergold, 1995). Based on conodont biostratigraphy, the Tsinania-Ptychaspis Zone, the basal zone of the Fengshanian, coincides with the Proconodontus tenuiserratus Zone; the superjacent Changia (or Quadraticephalus) Zone with the P. muelleri and P. posterocostatus Zone; and the Mictosaukia Zone with the Cambrooistodus minutus and Eoconodontus notchpeakensis Zones. The Missiquoia Zone both in China and North America coincides with the Cordylodus proavus Zone (An, 1982; Mei, 1993; An and Mei, 1994, Wang, 1984). Based on the trilobite biostratigraphy, Howell (1947) was the first to suggest that the Chinese Tsinania-Ptychaspis Zone may be correlative with the Ptychaspis-Prosaukia Zone of the late Franconian Stage in Wisconsin, USA. According to Miller (1969) and Miller et al. (1982), this trilobite zone is also equivalent to the Proconodontus tenuiserratus Zone. In Australia, the upper part of the P. muelleri Zone to the top of the Eoconodontus Zone are equivalent to the Payntonian Stage; the Lophosaukia Zone of the top of the Iverian Stage is correlated with the lower part of the P. muelleri Zone and upper part of the $P$. posterocostatus Zone; the Hapsidocare Zone is said to be equivalent to the lower part of the $P$. posterocostatus Zone and probably the $P$. tenuiserratus Zone, in the text, but not in column 6 of the conodont biostratigraphic sequence on the correlation chart (Shergold, 1995). The base of the Fengshanian, or the base of the Tsinania-Ptychaspis Zone, is correlated with the base of the Hapsidocare Zone rather than within the middle part of this Zone (Chang and Jell, 1987: 34). If this is the case, the late Cambrian conodont and trilobite 
biostratigraphies in China, Australia and North America are all coincident. For instance, the first appearance of saukiid and ptychaspid trilobites is in the TsinaniaPtychaspis Zone of the Fengshanian in China, the Hapsidocare Zone in Australia and the ProsaukiaPtychaspis Zone of the late Franconian in North America. In North America, Eastern Asia and Australia, the late Upper Cambrian conodont biostratigraphy is also similar. The Idamean of Australia can be correlated with the Chuangia Zone; the succeeding Peichiashania Zone may be regarded as the equivalent with the Chinese Maladioidella and Kaolishania Zones. The Lophosaukia and Hapsidocare Zones of late Iverian age should be correlated to the lower part of the Changia Zone and the Tsinania-Ptychaspis Zone respectively. The Payntonian Stage is equivalent to the upper part of the Changia Zone and the Mictosaukia Zone of the late Fengshanian Stage in China. It should be mentioned that "Tsinania" nomas (=Shergoldia nomas) differs from Tsinania canens not only in cranidial and pygidial features but also in different stratigraphic position.

The Karatau Range in southern Kazakhstan is the westernmost extension of the Tienshan Mountains which extends more than $2,000 \mathrm{~km}$ in an east-west trend between Chinese Xinjiang and Kazakhstan. Cambrian rocks are well exposed in the Malyj Karatau area, southern Kazakhstan. Since the publication of the Cambrian trilobites and biostratigraphic sequence from the sections of the Batyrbay and Kyrshabakty areas (Ergaliev, 1980), it deserves special attention by the Cambrian geologists and palaeontologists around the world. The lower and upper boundaries of the Cambrian System in Malyj Karatau, southern Kazakhstan are the same as those in southwestern China; the Cambrian zonal scheme of southern Kazakhstan can be correlated with those in Xinjiang, Hunan and Zhejiang, western and southern China respectively. Because of lack of fossil evidence from Malyj Karatau, it is impossible to discuss the Lower-Middle Cambrian boundary between China and southern Kazakhstan. The Middle-Upper Cambrian boundary in southern Kazakhstan is slightly different from that of China, but the trilobite sequence is the same. The Tremadocian biostratigraphy and the early Lower Cambrian phosphorite deposits in southern Kazakhstan are also the same in southwest China. From the facts mentioned above, I was surprised to find the great similarity of both the Cambrian biostratigraphy and trilobite faunas within the slope biofacies in China and southern Kazakhstan. Metaredlichioides, an Early Cambrian redlichioid from southwest and west China, is a junior synonym of Ushbaspis from southern Kazakhstan. Kazakhstan should be included within the Redlichian Realm during the Early Cambrian, and within the same faunal province as China in the Middle and Late Cambrian. A brief Cambrian correlation for the stages in China and Kazakhstan is shown in figure 3.

The correlation of the Cambrian Fauna 1-7 in Antarctica has been discussed in great detail by Cooper and Shergold (1991); it seems not necessary to repeat it here.

\section{ACKNOWLEDGEMENTS}

I would like to thank Professor A. R. Palmer, Institute for Cambrian Studies, Boulder (U.S.A.), and Dr. P. A. Jell, Queensland Museum, Brisbane (Australia) for patiently reading and correction of the manuscript, and for many excellent suggestions; to José A. Gámez, Universidad de Extremadura at Badajoz (Spain), and Professor E. Liñán, Universidad de Zaragoza (Spain), for helpful comments on the original manuscript and for editorial work that has improved the text. Special appreciation is also extended to José A. Gámez Vintaned for re-drawing three text-figures.

\section{REFERENCES}

Abdulin, A. A. and Chakabaev, E. E. 1984. Geology and phosphorite deposits in Malyj Karatau Ridge. Guidebook Excursions No. 045A and No. 101A. XXVII International Geological Congress, Moscow, 1984, 1-80.

An, T. X. 1982. Study on the Cambrian conodonts from North and Northeast China. Institute of Geosciences, University of Tsukuba, Science Reports, (B), 3, 113-159.

An, T. X. and Mei Shi-long. 1994. On the evolution of Cambrian conodonts. Acta Palaeontologica Sinica, 33 (5), 525-544. [In Chinese with English abstract.]

Bengtson, S., Conway Morris, S., Cooper, B. J., Jell, P. A. and Runnegar, B. N. 1990. Early Cambrian fossils from South Australia. Association of Australasian Palaeontologists Memoir, 9, 1-364.

Chang, W. T. 1957. Preliminary note on the Lower and Middle Cambrian stratigraphy of Poshan, central Shantung. Acta Palaeontologica Sinica, 5, 13-31. [In Chinese with English abstract.]

Chang, W. T. 1964. The boundary between the Lower and Middle Cambrian with description of some ptychoparioid trilobites. Nanjing Institute of Geology and Palaeontology, Academia Sinica, Science Press, Beijing. 38 pp. [In Chinese.]

Chang, W. T. 1980. A review of the Cambrian of China. Journal of the Geological Society of Australia, 27, 137 150.

Chang, W. T. 1981. On the northward drift of the AfroArabian and Indian Plates. Proceedings of the Royal Society of Victoria, 92 (2), 181-185.

Chang, W. T. 1984. Precambrian-Cambrian boundary problem. In: Contribution to 27th International Geological Congress, 1984, Moscow. Academia Sinica, Beijing, 41-51.

Chang, W. T. 1986. Correlation of the Cambrian of China. Palaeontologia Cathayana, 3, 267-286.

Chang, W. T. 1988. Correlation chart and explanatory notes. In: The Cambrian System in Eastern Asia. (Eds. J. H. Shergold and A. R. Palmer). International Union of Geological Sciences Publication, 24, 1-81.

Chang, W. T. 1989. World Cambrian biogeography. In: Development in Geosciences. Academia Sinica Contribution to 28th International Geological Congress, 1989, Washington, D.C., USA. Science Press, Beijing, 209-220. 
Chang, W. T. 1996. Notes on the Swedish Drepanura eremita Westergård, 1947. In: Centennial Memorial Volume of Prof. Sun Yunzhu (Y. C. Sun). Palaeontology and Stratigraphy. (Eds. H. Z. Wang and X. L. Wang). Chinese University of Geosciences Press, Beijing, 69-73.

Chang [Zhang] Wen-tang and Jell, P. A. 1987. Cambrian trilobites of North China: Chinese Cambrian trilobites housed in the Smithsonian Institution. Science Press, Beijing. 459 pp.

Chang [Zhang] Wen-tang, Lu Yan-hao, Zhu Zhao-ling, Qian Yi-yuan, Lin Huan-ling, Zhou Zhi-yi, Zhang Sen-gui and Yuan Jin-liang. 1980. Cambrian trilobite faunas of Southwest China. Palaeontologia Sinica, 159, New Series B, 16, 1-497. [In Chinese with English summary.]

Chang [Zhang] Wen-tang, Xiang Li-wen, Liu Yin-huan and Meng Xian-son. 1995. Cambrian stratigraphy and trilobites from Henan. Palaeontologia Cathayana, 6, 191.

Chang, W. T., Repina, L. N. and Geyer, G. 1997. Suborder Redlichiina Richter, 1932. In: Treatise on Invertebrate Paleontology. Part O. Arthropoda 1. Trilobita, Revised. Volume 1: Introduction, Order Agnostida, Order Redlichiida. (Ed. R. L. Kaesler). The Geological Society of America, Inc. and the University of Kansas, Boulder, Lawrence, 429-470.

Cobbold, E. S. 1935. Lower Cambrian faunas from Hérault (France). Annals and Magazine of Natural History, Series 10, 16, 25-48.

Cooper, R. A. and Shergold, J. H. 1991. Palaeozoic invertebrates of Antarctica. In: The Geology of Antarctica. (Ed. R. J. Tingey). Oxford Monographs on Geology and Geophysics, 17, Oxford Science Publications, Clarendon Press, Oxford, 455-486.

Courtessole, R. et Jago, J. B. 1980. Biostratigraphie du Cambrien inférieur du Cabardes (versant sud de la Montagne Noire, France Méridionale). Mémoire de la Société d'Études Scientifiques de l'Aude, 1-26.

Courtessole, R., Termier, G. et Termier, H. 1971. Le Cambrien inférieur terminal de Ferrals-les-Montagnes (Hérault). Bulletin de la Société d'Histoire Naturelle de Toulouse, 107 (1-2), 339-356.

Courtessole, R., Pillet, J. et Vizcaïno, D. 1988. Stratigraphie et paléontologie du Cambrien moyen gréseux de la Montagne Noire (versant méridional). Mémoire de la Société d'Études Scientifiques de l'Aude, 1-55.

Dean, W. T. 1982. Middle Cambrian trilobites from the Sosink Formation, Derik-Mardin district, southeastern Turkey. Bulletin of the British Museum (Natural History), Geology Series, 36 (1), 1-41.

Dean, W. T. and Özgüil, N. 1994. Cambrian rocks and faunas, Hudai area, Taurus Mountains, SE Turkey. Bulletin de L'Institut Royal des Sciences Naturelles de Belgique, Science de la Terre, 64, 5-20.

Endo, R. and Resser, C. E. 1937. The Sinian and Cambrian formartions and fossils of southern Manchukuo. Manchukuo Science Museum Bulletin, 1, 1-474.

Ergaliev, G. Kh. 1980. Trilobity srednego i verkhnego kembrija Malogo Karatau. [Middle and Upper Cambrian trilobites of Malyj Karatau.] Nauka, Kazakh SSR, Alma Ata. 212 pp. [In Russian.]
Feist, G. et Courtessole, R. 1984. Découverte de Cambrien supériour à trilobites de type estasiatique dans la Montagne Noire (France méridionale). Comptes Rendus de l'Académie des Sciences, Série II, 298 (5), 177-182.

Fortey, R. A. 1994. Late Cambrian trilobites from the Sultanate of Oman. Neues Jahrbuch für Geologie und Paläontologie, Abhandlungen, 194 (1), 25-53.

Fortey, R. A. and Rushton, A. W. A. 1976. Chelidonocephalus trilobite fauna from the Cambrian of Iran. Bulletin of the British Museum (Natural History), Geology, 36, 63-75.

Geyer, G. 1990. Revised Lower to lower Middle Cambrian biostratigraphy of Morocco. Newsletters on Stratigraphy, $22(2 / 3), 53-70$.

Geyer, G. and Elicki, O. 1995. Lower Cambrian trilobites from the Görlitz Synclinorium (Germany) - review and new results. Paläontologische Zeitschrift, 69 (1/2), 87 119.

Geyer, G. and Landing, E. 1995. The Cambrian of the Moroccan Atlas region. In: Morocco '95. The LowerMiddle Cambrian standard of western Gondwana. Introduction, Field Guide, Abstracts, and Proceedings of the First Conference of the Lower Cambrian Stage Subdivision Working Group and I.G.C.P. Project 366 Ecological Aspects of the Cambrian Radiation. (Eds. G. Geyer and E. Landing). Beringeria, Special Issue 2, 746.

Hamdi, B. 1989. Stratigraphy and palaeontology of the late Precambrian to Early Cambrian in the Alborz Mountains, northern Iran. Geological Survey of Iran, Report, 59, 141.

Hamdi, B., Brasier, M. D. and Jiang Zhi-wen. 1989. Earliest skeletal fossils from Precambrian-Cambrian boundary strata, Elburz Mountains, Iran. Geological Magazine, 126 (3), 283-289.

Howell, B. F. 1947. Cambrian correlation between China and North America. Bulletin of the Geological Society of China, 27, 141-162.

Hupé, P. 1953. Contribution à l'étude du Cambrien inférieur et du Précambrien III de l'Anti-Atlas Marocain. Notes et Mémoires du Service géologique de Maroc, 103, 1-402.

Hupé, P. 1960. Sur le Cambrien inférieur du Maroc. 21st International Geological Congress, Part 8, Late Precambrian and Cambrian Stratigraphy, 75-85.

Jell, P. A. 1986. An early Upper Cambrian trilobites faunule from Kashmir. Geological Magazine, 123 (5), 487-492.

Jell, P. A. 1990. Trilobita. In: Early Cambrian fossils from South Australia. (Auts. S. Bengtson, S. Conway Morris, B. J. Cooper, P. A. Jell and B. N. Runnegar). Association of Australasian Palaeontologists Memoir, 9, 257-322.

King, W. B. R. 1930. Notes on the Cambrian fauna of Persia. Geological Magazine, 67, 316-327.

King, W. B. R. 1937. Cambrian trilobites from Iran (Persia). Memoirs of the Geological Survey of India, Palaeontologica Indica, (new series), 22 (5), 1-22.

King, W. B. R. 1941. The Cambrian fauna of the Salt Range of India. Records of the Geological Survey of India, $\mathbf{7 5}$ (1940), Professional Paper 9, 1-15.

Kobayashi, T. 1934. Middle Cambrian fossils from Kashmir. American Journal of Science, Vol. 27, 295-302. 
Kobayashi, T. 1935. The Cambro-Ordovician formations and faunas of South Chosen. Palaeontology. Part III: Cambrian faunas of South Chosen with a special study of the Cambrian trilobite genera and families. Journal of the Faculty of Science, Imperial University of Tokyo, Section II, 4 (2), 49-344.

Kobayashi, T. 1957. Upper Cambrian fossils from peninsular Thailand. Journal of the Faculty of Science, University of Tokyo, Section II, 10 (3), 367-382.

Kobayashi, T. 1967. The Cambro-Ordovician formations and faunas of South Korea. Part X. Stratigraphy of the Chosen Group in Korea. Sect. C. The Cambrian of eastern Asia and other part of the continent. Journal of the Faculty of Science, University of Tokyo, Section II, 16 (3), 381-535.

Kruse, P. D. 1990. Cambrian palaeontology of the Daly Basin. Northern Territory Geological Survey, Report, 7, $1-58$.

Kumar, G. and Verma, R. N. 1987. Early Cambrian trilobites (Tsanglangpuan Stage) from Vel Nagabal. Anantnag District, Jammu and Kashmir. Journal of the Palaeontological Society of India, 32, 131-135.

Kuo, Z. M. 1965. On new material of late Middle Cambrian trilobite fauna from Kaiping Basin, eastern Hopei. Acta Palaeontologica Sinica, 13, 640-647. [In Chinese with English abstract.]

Kushan, B. 1973. Stratigraphie und Trilobitenfauna in der Mila-Formation (Mitteikambrium-Tremadoc) im AlborzGebirge (N-Iran). Palaeontographica, Abteilung A, 144, 113-165.

Liñán, E. and Sdzuy, K. 1978. A trilobite from the Lower Cambrian of Córdoba (Spain) and its stratigraphical significance. Senckenbergiana lethaea, 59 (4-6), $387-$ 399.

Lotze, F. 1961. Das Kambrium Spaniens. Teil I: Stratigraphie. Akademie der Wissenschaften und der Literatur, Abhandlungen der mathematisch-naturwissenschaftlichen Klasse, 1961 (6), 283-498 (1-216).

Lu Yan-hao. 1957. Trilobites. In: Index Fossils of China. Invertebrates. Volume 3. Geological Publishing House, Beijing, 249-298. [In Chinese.]

Lu Yan-hao, Zhang Wen-tang, Qian Yi-yuan, Zhu Zhaoling, Lin Huan-ling, Zhou Zhi-yi, Zhang Sen-gui and Wu Hong-ji. 1974. Cambrian trilobites. In: Handbook of the Stratigraphy and Palaeontology of SW China. Nanjing Institute of Geology and Palaeontology, Academia Sinica, Science Press, Beijing, 82-107. [In Chinese.]

Luo Hui-lin. 1984. Subdivision and correlation of the Cambrian System in southeastern Yunnan. Acta Geologica Sinica, 58 (2), 87-96. [In Chinese with English abstract.]

Luo Hui-lin, Jiang Zhi-wen and Tang Liang-dong. 1994. Stratotype section for Lower Cambrian Stages in China. Yunnan Science and Technology Press, Kunming. 183 pp. [In Chinese with English abstract.]

Mansuy, H. 1912. Étude géologique du Yunnan oriental. Part 2: Paléontologie. Mémoires du Service Géologique de l'Indochine, 1 (2), 1-146.

Mansuy, H. 1916. Faunes cambriennes de l'extrème-Orient meridional. Mémoires du Service Géologique de
l'Indochine, 5 (1), 1-48.

Mei Shi-long. 1993. The biostratigraphy of the Middle and Late Cambrian conodonts and trilobites from Wanxian, Hebei. Journal of Stratigraphy, 17 (1), 11-24. [In Chinese.]

Miller, J. F. 1969. Conodont fauna of the Notch Peak Limestone (Cambrian-Ordovician), House Range, Utah. Journal of Paleontology, 43, 413-439.

Miller, J. F., Taylor, M. E., Stitt, J. H., Ethington, R. L., Hintze, L. F. and Taylor, J. F. 1982. Potential CambrianOrdovician boundary stratotype sections in the western United States. In: The Cambrian Ordovician boundary, sections, fossil distribution and correlation. (Eds. M. G. Bassett and W. T. Dean). Geological Series No.3, National Museum of Wales, Cardiff, 155-180.

Öpik, A. A. 1967. The Mindyallan fauna of north-western Queensland. Commonwealth of Australia, Bureau of Mineral Resources, Geology and Geophysics, Bulletin, 74, vol. 1 (text), 1-404, vol.2 (appendixes, plates and index), 1-166.

Öpik, A. A., 1975. Templetonian and Ordian Xystridurid trilobites of Australia. Bureau of Mineral Resources, Geology and Geophysics Bulletin, 121, 1-84.

Parnes, A. 1971. Late Lower Cambrian trilobites from the Timna area and Har 'Amram (southern Negev, Israel). Israel Journal of Earth-Sciences, 20, 179-205.

Pillola, G. L. 1991. Trilobites du Cambrien inférieur du SW de la Sardaigne, Italie. Palaeontographica Italica, 78, 1174.

Rasetti, F. 1972. Cambrian trilobite faunas of Sardinia. Atti della Accademia Nazionale dei Lincei, Memorie, Serie 8, 11 (sezione II, fasc. 1), 1-98.

Redlich, K. 1899. The Cambrian fauna of the eastern Salt Range. Memoirs of the Geological Survey of India, Palaeontologica Indica, new series, 1, 1-13.

Reed, F. R. C. 1910 The Cambrian fossils of Spiti. Memoirs of the Geological Survey of India, Palaeontologica Indica, new series, 10 (1), 1-71.

Reed, F. R. C. 1934. Cambrian and Ordovician fossils from Kashmir. Memoirs of the Geological Survey of India, Palaeontologica Indica, new series, 21 (2), 1-38.

Richter, R. und E. Richter, E. 1941a. Die Fauna des Unterkambriums von Cala in Andalusien. Abhandlungen der Senckenbergischen Naturforschenden Gesellschaft, 455, 1-90.

Richter, R. und Richter, E. 1941b. Das Kambrium am Toten Meer und die älteste Tethys. Abhandlungen der senckenbergischen naturforschenden Gesellschaft, 460, $1-50$.

Robison, R. A. 1984. Cambrian Agnostida of North America and Greenland. Part 1: Ptychagnostidae. The University of Kansas Paleontological Contributions, Paper, 109, 159.

Schindewolf, O. H. und Seilacher, A., 1955. Beiträge zur kenntnis des Kambriums in der Salt Range (Pakistan). Akademie der Wissenschaften und der Literatur in Mainz, mathematisch-naturwissenschaftliche Klasse, Abhandlungen, 10, 257-446.

Sdzuy, K. 1962. Neue kambrische Fossilien aus Bohrungen im Gebiet von Doberlug. Geologie, 11 (9), 1087-1101. 
Sdzuy, K. 1978. The Precambrian-Cambrian boundary beds in Morocco (preliminary report). Geological Magazine, 115 (2), 83-94.

Shergold, J. H. 1993. The lverian, a proposed Late Cambrian Stage, and its subdivision in the Burke River Structural Belt, western Queensland. Bureau of Mineral Resources, Journal of Australian Geology and Geophysics, 13, 345358.

Shergold, J. H. 1995. Timescales calibration and development. 1. Cambrian. Australian Geological Survey Organisation Record, 1995/30, 1-32.

Shergold, J. H. and Sdzuy, K. 1984. Cambrian and Early Tremadocian trilobites from Sultan Dag, central Turkey. Senckenbergiana lethaea, 65 (1-3), 51-135.

Shergold, J. H. and Sdzuy, K. 1991. Late Cambrian trilobites from the Iberian Mountains, Zaragoza Province, Spain. Beringeria, 4, 193-235.

Shergold, J. H., Liñán, E. and Palacios, T. 1983. Late Cambrian trilobites from the Najerilla Formation, northeastern Spain. Palaeontology, 26 (1), 71-92.

Shergold, J. H., Burrett, C., Timothy, A. and Stait, B. 1988. Late Cambrian trilobites from Tarutao Island, Thailand. New Mexico Bureau of Mines and Mineral Resources Memoir, 44, 303-320.

Shergold, J. H., Laurie, J. R. and Sun Xiao-wen. 1990. Classification and review of the trilobite order Agnostida Salter,1864: an Australian perspective. Bureau of Mineral Resources, Geology and Geophysics, Report, 296, 1-70.

Sundberg, F. A. 1994. Corynexochida and Ptychopariida (Trilobita, Arthropoda) of the Ehmaniella Biozone (Middle Cambrian), Utah and Nevada. Contributions in
Science, 446, 1-137.

Tchernisheva, N. Ye. 1962. Kembriiskie trilobity semejstva Oryctocephalidae. [Cambrian trilobites of the Family Oryctocephalidae.] In: Problemy neftegazonosnosti Sovetskoj Arktiki. Paleontologija i biostratigrafija 3. Trudy nauchno-issledovatel'skogo geologicheskogo Instituta Arktiki, 127, 3-52. [In Russian.]

Walcott, C. D. 1905. Cambrian fauna of China. U. S. National Museum Proceedings, 29, 1-106.

Wang Zhi-hao. 1984. Late Cambrian and Early Ordovician conodonts from North and Northeast China with comments on the Cambrian-Ordovician boundary. In: Stratigraphy and Palaeontology of Systemic boundaries in China. Cambrian-Ordovician Boundary. 2. Nanjing Institute of Geology and Palaeontology, Academia Sinica, Science Press, Beijing, 195-272.

Whittington, H. B. 1986. Late Middle Cambrian trilobites from Zanskar, Ladakh, northern India. Rivista Italiana di Paleontologia e Stratigrafia, 92 (2), 171-188.

Wittke, H. W. 1984. Middle and Upper Cambrian trilobites from Iran: their taxonomy, stratigraphy and significance for provincialism. Palaeontographica, Abteilung A, 183, 91-161.

Wolfart, R. 1974a. Die fauna (Brachiopoda, Mollusca, Trilobita) aus dem Unter-Kambrium von Kerman, Sudost Iran. Geologische Jahrbuch (Reihe B), 8, 5-70.

Wolfart, R. 1974b. Die fauna (Brachiopoda, Mollusca, Trilobita) des älteren Ober-Kambriums (OberKushanian) von Dorah Shah Dad, Südost Iran, und Surkh Bum, Zentral-Afghanistan. Geologische Jahrbuch (Reihe B), 8, 71-184. 